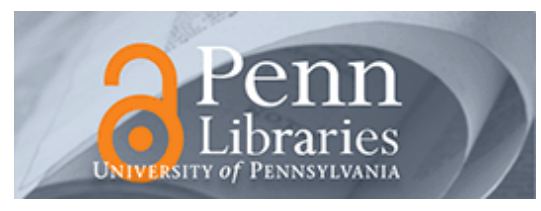

University of Pennsylvania

ScholarlyCommons

Accounting Papers

Wharton Faculty Research

$5-2002$

\title{
Discussion of Real Investment Implications of Employee Stock Option Exercises
}

Wayne R. Guay

University of Pennsylvania

Follow this and additional works at: https://repository.upenn.edu/accounting_papers

Part of the Accounting Commons

\section{Recommended Citation}

Guay, W. R. (2002). Discussion of Real Investment Implications of Employee Stock Option Exercises. Journal of Accounting Research, 40 (2), 395-406. http://dx.doi.org/10.1111/1475-679X.00053

This paper is posted at ScholarlyCommons. https://repository.upenn.edu/accounting_papers/31

For more information, please contact repository@pobox.upenn.edu. 


\section{Discussion of Real Investment Implications of Employee Stock Option Exercises}

Disciplines

Accounting 


\title{
Discussion of: Real Investment Implications of Employee Stock Option Exercises
}

\author{
Wayne Guay \\ The Wharton School \\ University of Pennsylvania \\ 2400 Steinberg-Dietrich Hall \\ Philadelphia, PA 19104-6365 \\ email: guay@wharton.upenn.edu \\ phone: (215) 898-7775 \\ fax: (215) $573-2054$
}

December, 2001

I would like to thank John Core and Abbie Smith (editor) for their helpful comments. I gratefully acknowledge financial support from the Wharton School. Any errors or omissions are the sole responsibility of the author. 


\section{Introduction}

Bens, Nagar and Wong [BNW, 2001] investigate how employee stock option plans influence corporate payout policy and investing decisions. BNW hypothesize that firms divert cash from profitable investment expenditures to fund share repurchases in an attempt to mitigate earnings-per-share (EPS) dilution from stock option exercises. The relation between corporate finance, managerial incentives and investing decisions is a rich and important area of academic research. In recent years, the widespread growth in employee stock option plans has spurred increased interest on the part of shareholders, regulators and academics as to the effects of these plans on financing activities, incentives and equity valuation. Further, there is growing evidence that managers are concerned with the financial accounting implications of stock options plans (e.g., Carter and Lynch, 2001).

BNW motivate their study with four assumptions about managerial behavior. The first assumption is that managers believe employee stock option exercises "dilute" EPS. Second, BNW assert that managers believe share repurchases mechanically increase EPS. Third, BNW assume that managers and/or investors myopically focus on short-term EPS. The fourth critical assertion is that BNW's sample of S\&P 500 firms have severe cash constraints and high financing costs (e.g., low free cash flow, small reserves of liquid assets, and no source of inexpensive short-term debt financing) that force managers to fund EPS-motivated share repurchases with cash diverted from profitable investment projects.

Under these assumptions, BNW interpret their empirical results as consistent with the hypotheses that: 1) firms repurchase shares in response to top-five executives' option 
exercises to mitigate EPS dilution, 2) firms finance these repurchases by decreasing $R \& D$ and capital expenditures, and 3) this diversion of investment expenditures imposes immediate costs on the firm in the form of declines in the following years' earnings-toassets ratio.

Conference participants questioned the validity of all four of these assumptions. They had difficulty reconciling the notion of stock option "dilution" with an economic setting where firms, on average, use the optimal quantity of options for compensation and incentive purposes. Participants also questioned how the above assumptions could be reconciled with the economic prediction that managers have rational expectations about the effects of share repurchases on EPS. First, why would top executives, who are experts in applied accounting and finance, believe that options dilute EPS or that share repurchases mechanically increase EPS? As noted in Section 3 below, because firms forego earnings on cash used for share repurchases, repurchase activity is likely to decrease EPS for a large fraction of BNW's sample firms. Second, why would managers divert funds from investment expenditures when much less costly sources of funds appear readily available? Section 4 provides evidence that BNW's sample firms have ample cash reserves and free operating cash flow, and access to low-cost short-term borrowing. Third, participants questioned whether BNW could identify a plausible contracting environment under which managers of S\&P 500 firms find it optimal to myopically increase this year's EPS at the expense of next year's eamings. Finally, in light of the concerns about the underlying hypotheses, as well as econometric issues surrounding the tests, there was a general skepticism about whether the empirical results are interpretable. 
This discussion focuses primarily on the validity of the four main assumptions underlying BNW's hypotheses and empirical tests. Sections 2 through 5 examine the four assumptions in detail and suggest there is reason to believe these assertions are either incorrect or tenuous. Section 6 briefly offers some alternative hypotheses about economic relations between share repurchases and employee stock option plans. Concerns about the empirical tests are highlighted in Section 7. Section 8 offers concluding remarks.

\section{Do stock option plans "dilute" EPS?}

To assess whether employee stock options are "dilutive", it is important to first consider the economic and accounting issues underlying the options-related transactions between firms and their employees. Nearly all large public corporations have an employee stock option plan. Granting options to employees is conceptually similar to raising capital through issuing stock. Employees receive an equity stake in the corporation in return for services rendered. Like any other factor in production, corporations use these employee services to earn profits. However, unlike other factors in production, grants of options are not expensed in earnings. As such, other things equal, the earnings of firms that grant options extensively are expected to be greater than the earnings of firms that use no options.

The emphasis of BNW is not on earnings, but rather on EPS. Specifically, BNW are concerned with how options "dilute" EPS. Although BNW do not define EPS dilution, it seems that their notion of EPS dilution relates to whether and how employee stock option plans decrease EPS (through their effect on the number of shares included in the denominator of EPS). Given that managers and investors do not ignore the value inherent in stock options, warrants, and other convertible securities (e.g., Aboody, 1996), 
it is reasonable to focus on diluted EPS as opposed to basic EPS (diluted EPS incorporates equity positions that are convertible into common stock, whereas basic EPS does not). Conference participants asked BNW to more precisely define option dilution.

BNW argue that option exercise reflects a dilutive transfer of value from shareholders to employees. This seems incorrect in light of the following observations. As noted above, at the option grant date, the firm is expected to transfer equity value to employees in return for services of equal value. The employees then become partial owners of the firm and share in any future earnings growth and stock price appreciation. Empirical evidence suggests that investors understand that options are a form of equity when setting stock prices (e.g., Aboody, 1996). Thus, price incorporates investors' assessment of the equity value and the claim on earnings inherent in outstanding options. In this context, the notion that stock options dilute EPS seems inappropriate. That is, nearly all forms of equity finance, such as common stock and most stock-based securities (e.g., convertible debt, warrants, convertible preferred stock) contribute to the shares used to compute the denominator of EPS. Why are stock options singled out as being dilutive?

BNW focus on the option exercise date as the trigger that causes firms to be concerned about stock option dilution. However, the significance of the exercise date in this respect is unclear given that the option exercise date is simply the date at which the employee decides to trade the exercise price for a share of stock. At the grant date, firms certainly understand that the typical long-maturity option has a greater than $90 \%$ probability of finishing in-the-money (e.g., see Lambert, Larcker, and Verrecchia, 1991), and that employees will always exercise vested in-the-money options prior to cancellation. 
Even from a mechanical perspective, conference participants found it difficult to see why managers are concerned about EPS dilution at the time of option exercise, or why mitigating this concern would consume significant additional capital. To see this, note that the effect of options on the denominator of diluted EPS is computed under the treasury-stock method. The treasury-stock method counts each option as (1-X/P) shares of stock, where $\mathrm{P}$ is the average stock price over the fiscal year and $\mathrm{X}$ is the option exercise price (for options granted or exercised during the year, $\mathrm{P}$ and $\mathrm{X}$ are weighted by the fraction of the year the option is outstanding). The treasury-stock method shares are added to common stock shares to compute the denominator of diluted EPS. Because most options are granted at-the-money (i.e., $\mathrm{X}=\mathrm{P}$ ), $1-\mathrm{X} / \mathrm{P}$ is generally zero at the grant date. As the stock price rises over time, 1-X/P becomes positive, and the denominator of diluted EPS increases. At the exercise date, the firm issues a share of stock to the employee in return for the exercise price, (i.e., the employee receives value equal to $\mathrm{P}-\mathrm{X}$ ).

Just prior to option exercise, an option's contribution to the denominator of diluted EPS is $1-\mathrm{X} / \mathrm{P}$. After exercise, the contribution of the additional outstanding share to the denominator is 1 . But the firm also has the exercise proceeds (and if it has a positive marginal tax rate, it often obtains cash tax savings for the compensation expense deduction received upon option exercise). If the firm uses the exercise proceeds to repurchase shares, the post-exercise effect on the denominator is 1-X/P: no effect on EPS and no "dilution" occurs. Note that cash beyond the exercise proceeds is not necessary to hold option "dilution" constant. ${ }^{1}$

\footnotetext{
1 This point raises measurement issues with respect to BNW's measure of option exercise activity (ESOEX). ESOEX is measured by BNW as the market price of the shares at the time of exercise less the strike price paid by the employees: $(\mathrm{P}-\mathrm{X})^{*}$ number of options exercised. Since this "dilution" measure is already included in the denominator of diluted EPS prior to exercise, it is not clear why this measure
} 
To counter this argument, BNW note that when stock prices rise over time, treasury-stock method shares at the exercise date can be greater than the treasury-stock method shares in the previous period's EPS (i.e., $1 \mathrm{X} / \mathrm{P}_{\mathrm{t}}>1-\mathrm{X} / \mathrm{P}_{\mathrm{t}-1}$ ). They suggest that if firms view prior period EPS as a benchmark, then additional cash beyond the exercise proceeds may be necessary to mitigate the increase in $1 \mathrm{X} / \mathrm{P}$ that has occurred since the previous fiscal period. There are at least two problems with this argument. First, BNW's sample firms experienced substantial growth in EPS during the 1996-1999 period, making it unlikely that these firms were concerned about meeting prior year EPS. Median one-year EPS growth was approximately $13 \%$ for the full sample and $22 \%$ for the quartile of firms with the greatest option exercises (as measured by ESOEX). ${ }^{2}$ Second, BNW's "dilution avoidance prediction" suggests that dilution from total options outstanding, and not option exercises, is the correct variable of interest. That is, $1-\mathrm{X} / \mathrm{P}$ increases whenever the stock price increases, regardless of whether or not the option is exercised. BNW argue that because a dilution avoidance perspective gives firms no reason to repurchase shares at the time of grant (i.e., $1-\mathrm{X} / \mathrm{P}=0$ ), they choose to conduct their tests on option exercises. However, it seems that BNW's tests would be more consistent with their underlying arguments if their dilution avoidance hypothesis

\footnotetext{
captures firms' concerns about EPS dilution at the time options are exercised. However, given that the authors do not define the term "option dilution," it is difficult to definitively determine the appropriate dilution measure.

2 These figures are not reported in BNW. To estimate these measures, data were drawn from the Compustat and Execucomp databases using the procedures described in BNW. The descriptive statistics for this replicated sample are nearly identical to the descriptive statistics reported in BNW's Table 1.
} 
predicted that repurchases occur over time as $1 \mathrm{X} / \mathrm{P}$ increases for all outstanding options (e.g., as in Weisbenner, 2000). ${ }^{3}$

\section{Do share repurchases increase diluted EPS?}

Share repurchases can be an efficient payout method and an effective signaling technique (e.g., Dann, 1981; Ofer and Thakor, 1987; Barclay and Smith, 1988). However, as noted by conference participants, in efficient capital markets, repurchasing shares has no mechanical effect on firm value. That is, in the absence of an economic motivation, share repurchases simply reflect a value-neutral transfer of cash for stock. In the BNW framework, managers are assumed to be motivated to repurchase shares, not because they are maximizing firm value, but instead because they are myopically focused on shortterm EPS. The following section illustrates that repurchases can have a mechanical relation with EPS, but that for most S\&P 500 firms during the 1996-1999 sample period, repurchases are likely to have mechanically decreased, not increased, short-term EPS.

BNW argue that, "Repurchases decrease the number of shares outstanding and have no direct effect on earnings, thus increasing EPS (italics emphasis added)." Examples of this perspective can also be found in the practitioner literature. For example, in a 2001 Journal of Applied Corporate Finance (JACF, 2001, p29) roundtable discussion of capital structure and stock repurchases, Donald Chew of Stern Stewart \&

\footnotetext{
${ }^{3}$ Although BNW provide a robustness check to explore whether share repurchases lead option exercises, this test appears to be misspecified. Specifically, in their baseline regression of share repurchases on ESOEX (i.e., the stock price less the strike price for exercised options), the authors include future values of ESOEX. However, the portion of future ESOEX that is uncorrelated with current values of ESOEX is likely to be largely unpredictable because future option exercises depend on future realizations of stock returns. In others words, unless firms can predict future stock returns, it seems very unlikely that current share repurchases can be explained by future option exercises. A more appropriate test would use contemporaneous unexercised options (possibly considering the extent to which these options have recently moved in-the-money) as additional independent variable(s) to explain share repurchases.
} 
Co. asks, "Dave [Ikenberry], you've mentioned four reasons to buy back stock. But isn't there a fifth motive - namely, to increase earnings per share?"

The effect of share repurchases on EPS is straightforward and depends on the relative numerator and denominator effects. The numerator of EPS reflects fiscal period earnings and the denominator reflects weighted average shares outstanding during the fiscal period (e.g., shares repurchased at fiscal period end have no effect on EPS whereas shares repurchased at fiscal year beginning are subtracted from shares outstanding for the full year). Repurchasing shares requires the payout of cash. Whether share repurchases increase or decrease short-term EPS depends on whether the foregone return on cash used for repurchases is less than or greater than the ratio of the firm's earnings to the market value of equity (i.e., the earnings-to-price ratio). This argument was made by conference participants and is well articulated by Richard Thevenet, Assistant Treasurer of PepsiCo:

The size of any EPS increase [from share repurchases] depends on the algebraic relationship between the firm's E/P ratio (the inverse of its $\mathrm{P} / \mathrm{E}$ ) and the return on its cash. If you earn $5 \%$ after taxes on your cash, the buybacks are accretive only if your $\mathrm{P} / \mathrm{E}$ is less than 20 - that is, only if your $\mathrm{E} / \mathrm{P}$ is above $5 \%$. There is no information content in the accretion, no value creation; it's just simple algebra. And since the S\&P 500 has an average $\mathrm{P} / \mathrm{E}$ of 27 , the average S\&P 500 company would actually suffer dilution from stock buybacks in the first year or two. (JACF, 2001, p29)

Thevenet goes on to note that incomplete analysis tends to miss this point:

Now, a lot of sellside analysts talk about earnings pick-up. But when they do their analysis, they almost always fail to consider that the cash used to repurchase stock would otherwise have been used to pay down debt or to generate interest income....So, this great EPS effect is mainly an illusion. If you do the math right, it just doesn't exist. (JACF, 2001, p29)

BNW provide no empirical evidence that share repurchases increase short-term EPS. Instead, they document a positive contemporaneous relation between share repurchases and option exercises by top-five executives and indirectly infer that 
managers repurchase shares to increase EPS. However, as noted above, if managers have rational expectations about the effect of repurchases on EPS, this inference is extremely tenuous.

An alternative economic explanation for a positive relation between repurchases and option exercises is that firms choose to repurchase shares when they face excess cash from the proceeds of unexpectedly large stock option exercises. The magnitude of the options-related repurchases documented by $\mathrm{BNW}$ appears consistent with this interpretation. In Table 3, BNW regress dollar share repurchases on top-five executives' option exercises, where exercises are measured as the market price of the shares at the time of exercise less the strike price paid by the employee. ${ }^{4}$ As noted by BNW, the coefficient of 1.19 on ESOEX in Table 3 implies that firms, on average, repurchase $\$ 1.19$ of stock for every $\$ 1$ that the market price exceeds the strike price. Recall that ESOEX is defined as $(\mathrm{P}-\mathrm{X})$ times the number of shares exercised. This coefficient also implies that the cash used for options-related repurchases is less than the exercise proceeds if the average price-to-strike ratio of exercised options is less than 1.84 :

$$
1.19(\mathrm{P}-\mathrm{X})<\mathrm{X} \Rightarrow \mathrm{P} / \mathrm{X}<1.84 \text {. }
$$

For the sample of firms used in this study, the median price-to-strike ratio of the options exercised by top-five executives is about $2.1 .^{5}$ This ratio is likely to be somewhat smaller for option exercises by lower-level employees who generally exercise earlier (e.g.,

\footnotetext{
${ }^{4}$ It is useful to note that all of BNW's hypotheses relate to firm-wide stock option plans. BNW use data on top-five executives' stock options as a proxy for firm-wide plans. There is evidence that exercise behavior of top-five executives differs from that of other employees and that there are industry differences in the proportion of firm-wide options granted to top executives (e.g., Huddart and Lang, 1996; Core and Guay, 2001). Thus, BNW's proxy for firm-wide option exercise activity is likely to measure the desired construct with non-random error.

${ }^{5}$ The data to compute this ratio are obtained as described in Footnote 2. To estimate the price-to-strike ratios for exercised options, the fiscal year-end stock price is divided by the difference between the fiscal year-end stock price and the average in-the-money dollar amount per option exercised.
} 
Huddart and Lang, 1996). Further, this analysis ignores the potential compensationexpense-related tax savings obtained by firms upon option exercise. Taken together, these arguments raise questions about whether the cash used to repurchase shares exceeds the proceeds from option exercises. If this counter analysis is accurate, it seems difficult to argue that the firm must reduce valuable investing expenditures to fund their optionsrelated repurchase activity, even in the absence of other sources of financing.

\section{Are cash constraints and financing costs sufficiently large that share repurchases must be funded by diverting cash from profitable investments?}

As noted by BNW, their hypothesis relies on a critical assumption that their sample of S\&P 500 firms face sufficient internal cash constraints and external financing constraints such that diverting cash from R\&D and capital expenditures is a cost-effective means of raising capital for share repurchases. Although BNW say that is it possible that their sample firms experience substantial cash and financing constraints, BNW provide no empirical support for this claim. Conference participants had difficulty understanding when or why these costs are expected to exceed the costs of diverting expenditures from valuable investments. BNW leave this question unanswered.

Analysis of the data do not support the assertion that the sample firms experience significant cash and financing constraints (data obtained as described in Footnote 2). Specifically, S\&P 500 firms have sufficient operating cash flow and cash reserves during the 1996-1999 period to fund both their repurchasing activity and their investment expenditures. The mean (median) dollar repurchases as reported in BNW's Table 1 is \$270 million (\$48 million). By comparison, the mean (median) reserve of cash and marketable securities is approximately $\$ 700$ million ( $\$ 180$ million). Among firms engaged in repurchasing shares, cash and marketable securities is $140 \%$ of the dollar 
share repurchases for the median firm. For the quartile of firms with the greatest option exercises (as measured by ESOEX), this percentage exceeds $200 \%$.

As another comparison, mean (median) free operating cash flow (after R\&D and capital expenditures) is approximately $\$ 620$ million $(\$ 210$ million). Among firms engaged in repurchasing shares, free operating cash flow is $145 \%$ of the dollar share repurchases for the median firm (the corresponding figure is $160 \%$ for the quartile of firms with the greatest option exercises).

A casual investigation of the credit ratings and financing ativities of the S\&P 500 sample reinforces the notion that these firms are unlikely to perceive reductions in investment expenditures as an attractive, cost-effective financing alternative. Among the sample firms engaged in repurchasing shares, approximately $70 \%$ have commercial paper ratings available on Compustat. Within this subsample, $95 \%$ have ratings of $\mathrm{A} 2$ or better, which indicates that when needed these firms can inexpensively raise short-term capital by accessing the debt markets (the pre-tax cost of A2 commercial paper is typically about 30 basis points above the yield on treasury securities of the same maturity). Further, the sample firms tend to be actively involved in debt financing activities. For example, in about $78 \%$ of the firm-years, capital is raised through issuance of debt (repayments of principal were roughly the same magnitude, resulting in little change in debt for the median firm).

\section{Are managers myopic with respect to short-term EPS?}

Firms in the S\&P 500 are among the most successful and well-managed firms in the world. BNW hypothesize that the managers of these firms systematically squander valuable investment opportunities in an obvious way because they are myopically fixated 
on short-term EPS. However, this assertion seems hard to reconcile with the observed high performance and low monitoring costs of the sample firms. Given that an attempt to manage earnings through share repurchases is readily observable by analysts, investors, and the board of directors, conference participants found it difficult to construct an economic explanation for why managers or shareholders benefit from this behavior. At the very least, BNW should provide some careful empirical evidence to support their assertion.

Among the hurdles in constructing such an explanation are the following: 1) Repurchasing shares with the proceeds from a reduction in investment expenditures is not necessary to manage short-term earnings upward. Cutting R\&D and capital expenditures is sufficient to increase earnings in the short-term. As noted in Section 3, repurchasing shares with cash diverted from these projects is likely to decrease EPS; 2) Virtually all top-executives in this sample enter into multi-year contracting arrangements that tie a substantial fraction of their wealth to the stock price (e.g., Hall and Liebman, 1998), and earnings-based incentives tend to be small relative to stock-price-based incentives for most CEOs (Core, Guay and Verrecchia, 2000). Considerable evidence suggests that stock prices are forward-looking and anticipate future earnings (e.g., Kothari and Sloan, 1992). Therefore, myopic behavior with respect to short-term EPS is costly to managers with substantial stock and option portfolios; 3) Because analysts can readily observe repurchase behavior, any influence of this activity on EPS is expected to be incorporated in forecasts, thereby mitigating the likelihood that this behavior will assist managers in meeting earnings forecasts. Also, because the study is conducted during a period of 
substantial earnings growth among the sample firms, a story where executives manage earnings to beat earnings from prior years seems implausible.

\section{Alternative hypotheses to motivate a relation between repurchases and employee stock option plans.}

In addition to BNW's myopic EPS hypothesis, there are alternative economic hypotheses that predict a relation between share repurchases and employee stock option plans. One such hypothesis is described in Section 3: firms view an unexpected increase in stock option exercise proceeds as a nonrecurring cash flow shock to be redistributed to stockholders in the form of share repurchases. Another possibility is that firms favor an optimal capital structure. When a firm grants options to employees in return for services rendered, the value of equity capital increases, and financial leverage decreases (on a market value basis). As options increase in value over time, financial leverage further decreases. If employee stock options move the firm away from its preferred target capital structure, one potential response is share repurchases to reduce leverage. Although this argument suggests a relation between share repurchases and employee stock options, it does not speak to share repurchases in response to option exercises. Still another possibility is that large option grants and exercises have the potential to dilute the voting interests of large blockholders. If these shareholders value their fractional ownership rights, some firms may respond by repurchasing shares to mitigate the ownership dilution caused by intensive employee stock option plans. Finally, the value of stock options is not dividend protected. That is, because optionholders are not entitled to receive dividends, option value is a decreasing function of dividend payments and, other things equal, optionholders will prefer to distribute cash through share repurchases rather than through dividends (e.g., Bartov, Krinsky and Lee, 1998). 


\section{Empirical issues}

In their concluding statements, $\mathrm{BNW}$ point out that their results are potentially not interpretable due to the endogenous determination of share repurchases, option exercises and investment expenditures. They argue that a serious attempt to correct these problems is beyond the scope of their study. While most empirical researchers can empathize with this situation, one cannot ignore potentially serious specification issues. Further, within this particular setting, previous research appears to shed insight into at least partial remedies for some of the specification problems.

For example, consider BNW's discussion of the role of share repurchases in corporate payout policy. They argue that, "If share repurchase is the optimal form of corporate payout for firms with ESOs, then one should see no future decline in delivered performance as a result of the cash spent to make these repurchases." This claim is in contrast to considerable empirical evidence that share repurchases precede mean reversion in cash flow and return on assets (e.g., Lie and McConnell, 1998; Guay and Harford, 2000). BNW attempt to document a decline in ROA following share repurchases and interpret this finding as evidence that firms' payout policy is suboptimal. However, the payout choice literature suggests an alternative inference; that firms optimally choose to repurchase shares in periods following positive performance but preceding periods of mean reversion in performance. This endogeneity problem can potentially be addressed by benchmarking the results in $\mathrm{BNW}$ against results in studies that examine random samples of firms that repurchase shares. 
A second endogeneity problem, noted by conference participants and by $\mathrm{BNW}$ in their concluding remarks, concerns simultaneity issues between option exercises and future performance, and between option exercises and option grants. The empirical literature on stock options contains several instrumented simultaneous models of exercise and grant behavior (e.g., Janakiraman, 1998; Core and Guay, 2001). While BNW claim that good instruments are unavailable to address the simultaneity problems in their study, this prior research and Heath, Huddart, and Lang [1999] suggest several possibilities.

In a few cases, BNW do attempt to control for certain simultaneity problems. For example, BNW predict and document a negative relation between option exercises and future investment expenditures and infer that firms reduce investment to fund optionsrelated share repurchases. However, BNW also note that an alternative hypothesis is that executives have private information about future performance and choose to exercise options when expected future performance is poor (part of BNW's "life cycle" affect). This potential simultaneity between exercises and future performance clouds interpretation of the results. To control for this problem in their regressions, $\mathrm{BNW}$ include measures such as the contemporaneous book-to-market ratio, historical volatility of ROA, and historical sales growth. However, if executives' exercise behavior is influenced by their private information about future changes in stock price, it is unlikely that including publicly available historical variables in the regression will control for this effect.

A separate empirical issue relates to whether the association between option exercises and investment expenditures documented by BNW is economically significant. To generate a measure of economic significance, BNW consider the effect of a one 
standard deviation change in ESOEX on investment expenditures (standard deviation = 0.0052). This measure is extremely misleading in that the cross-sectional standard deviation of ESOEX appears to be largely influenced by outliers. For example, note that the interquartile range of ESOEX is only 0.001 , or about one fifth of the standard deviation. It is safe to say that almost none of the sample firms experienced a change in ESOEX equal to 0.0052. Using instead the interquartile range of ESOEX to assess economic significance yields an expected decline in R\&D of $\$ 7$ million and a decline in capital expenditures of $\$ 4$ million. These numbers are very small compared to mean R\&D and capital expenditures of $\$ 416$ million and $\$ 764$ million, respectively. They are also very small when compared to the firms' reserves of cash and marketable securities $($ mean $=\$ 700$ million $)$ and free operating cash flow $(\$ 620$ million $)$.

A related issue is the plausibility of the coefficient magnitudes in BNW's regressions of future ROA on ESOEX. BNW report that a one standard deviation change in ESOEX results in a $\$ 55$ million decrease in investment expenditures for the average firm, and a $1.5 \%$ reduction in ROA. For the average firm with assets of $\$ 11.8$ billion, a $1.5 \%$ reduction in $\mathrm{ROA}$ is equivalent to a one-period ahead reduction in earnings of $\$ 177$ million; more than 3 times the $\$ 55$ million reduction in investment expenditures. Thus, if BNW's interpretation of these coefficients is accurate, it raises the question of why the sample firms are diverting funds from among their most profitable investment opportunities.

\section{Concluding remarks}

BNW (2001) investigate the relation between employee stock option plans, corporate payout policy and investing decisions. Specifically, BNW hypothesize that 
firms divert cash from profitable investment expenditures to fund share repurchases in an attempt to mitigate EPS dilution from stock option exercises. This discussion raises many concerns that the assumptions underlying BNW's hypotheses are either tenuous or incorrect. In particular, it is not clear that stock option plans dilute EPS or that share repurchases effectively increase EPS. Further, even if option plans did dilute EPS and repurchases could mitigate this dilution, the sample firms in this study appear to have sufficient internal funds and low cost access to external funds to finance their repurchase activities without diverting funds from investment. Finally, BNW provide no explanation or empirical support for the incentive structure that supports managers' myopic focus on short-term EPS.

For reasons not yet well understood, firms do appear to care about the financial accounting implications of employee stock option plans. There are also potential economic hypotheses that support a relation between stock option plans and payout choice (e.g., Bartov, Krinsky and Lee, 1998; Grullon and Michaely, 2000). As alluded to in $\mathrm{BNW}$, there may also be behavioral aspects of these relations. Research that ties these endogenously determined decisions together will provide insight into the role of employee stock option plans in the relation between corporate finance, managerial incentives and investing decisions. 


\section{References}

Aboody, D., 1996, Market valuation of employee stock options, Journal of Accounting and Economics 22: 357-391.

Barclay, M., and C. Smith, 1988, Corporate payout policy: Cash dividends versus openmarket repurchases, Journal of Financial Economics 22, 61-82.

Bartov, E., Krinsky, I., Lee, J., 1998, Evidence on how companies choose between dividends and open-market stock repurchases, Journal of Applied Corporate Finance 11, 89-96.

Carter, M., and L. Lynch, 2001, The effect of accounting on economic behavior: evidence from stock option repricing. Working paper, Columbia University.

Core, J., and W. Guay, 2001, Stock Option Plans for Non-executive Employees. Journal of Financial Economics, 61.

Core, J., W. Guay, and R. Verrecchia, 2000, Are Performance Measures other than Price Important to CEO Incentives? Working paper, University of Pennsylvania.

Dann, L., 1981, Common stock repurchases: an analysis of returns to bondholders and stockholders, Journal of Financial Economics 9, 113-138.

Grullon, G., and R. Michaely, 2000, Dividends, share repurchases, and the substitution hypothesis. Working paper, Rice University.

Guay, W. and Jarrad Harford, 2000, The cash-flow permanence and information content of dividend increases vs. repurchases. Journal of Financial Economics $57,385-$ 415.

Hall, B. J., and J. B. Liebman, 1998. Are CEOs really paid like bureaucrats? Quarterly Journal of Economics 113, 653-691.

Heath, C., Huddart, S., and M. Lang, 1999, Psychological factors and stock option exercise. Quarterly Journal of Economics 114, 601-628.

Huddart, S., Lang, M., 1996. Employee stock option exercises: an empirical analysis. Journal of Accounting and Economics 21, 5-43.

Janakiraman, S., 1998. Stock option awards and exercise behavior of CEOs: an empirical analysis. Working paper, University of Texas at Dallas. 
Kothari, S.P. and R.G. Sloan, 1992, Information in earnings about future earnings: Implications for eamings response coefficients. Journal of Accounting and Economics 15, 143-171.

Lambert, R.; D. Larcker, and R. Verrecchia, 1991. Portfolio considerations in valuing executive compensation. Journal of Accounting Research 29, 129-149.

Lie, E., McConnell, J., 1998, Earnings signals in fixed-price and Dutch auction selftender offers, Journal of Financial Economics 49, 161-186.

Ofer, A., Thakor, A., 1987, A theory of stock price responses to alternative corporate cash disbursement methods: stock repurchases and dividends, Journal of Finance 42, 365-394.

Stern Stewart Roundtable on Capital Structure and Stock Repurchase,2001, Journal of Applied Corporate Finance 14, 8-41.

Weisbenner, S., 2000, Corporate Share Repurchases in the 1990s: What Role Do Stock Options Play? Working paper, University of Illinois at Urbana-Champaign. 